\title{
Infectivity, transmission and 16S rRNA sequencing of a rickettsia, Coxiella cheraxi sp. nov., from the freshwater crayfish Cherax quadricarinatus
}

\author{
C. K. Tan, L. Owens* \\ Department of Microbiology and Immunology, James Cook University, Townsville 4811, Australia
}

\begin{abstract}
A rickettsia-like organism isolated from infected, farm-reared Cherax quadricarinatus was cultured in the yolk sac of developing chicken eggs, but could not be cultured in 3 continuous cell lines, bluegill fry (BF-2), fathead minnow (FHM), and Spodoptera frugiperda (Sf-9). The organism was confirmed by fulfilling Koch's postulates as the aetiological agent of mortalities amongst C. quadricarinatus. When C. quadricarinatus was inoculated with the organism, mortality was $100 \%$ at $28^{\circ} \mathrm{C}$ and $80 \%$ at an ambient temperature of $24^{\circ} \mathrm{C}$. Horizontal transmission with food and via the waterborne route was demonstrated, but mortalities were lower at 30 and $10 \%$ respectively over a 4 wk period. The $16 \mathrm{~S}$ rRNA sequence of 1325 base pairs of the Gram-negative, obligate intracellular organism was $95.6 \%$ homologous to Coxiella burnetii. Of 18 species compared to this rickettsia, the next most closely related bacterium was Legionella pneumophila at $86.7 \%$. The suggested classification of this organism is Order Rickettsiales, family Rickettsiaceae, tribe Rickettsieae, within the genus Coxiella. We suggest it should be named Coxiella cheraxisp. nov.
\end{abstract}

KEY WORDS: Cherax quadricarinatus - Crayfish - Rickettsia - Coxiella cheraxi

\section{INTRODUCTION}

The Australian redclaw crayfish Cherax quadricarinatus is a tropical freshwater crayfish native to river systems and waterways of northern Australia and southern Papua New Guinea (Jones 1990). It grows rapidly, is non-aggressive and can tolerate a wide range of conditions, thus making it an ideal species for aquaculture (Rouse 1995). Since its introduction into aquaculture, redclaw has generated a vast amount of interest throughout the world (Medley et al. 1994). It is currently cultured in the United States, South Africa, Israel, China, Taiwan, the Caribbean and Latin America (e.g., Ecuador) (Medley et al. 1994).

With the expansion of redclaw aquaculture, diseases have become more evident. To date, diseases have not threatened the industry as a whole, but they have on a local scale (Edgerton 1996). A number of viruses (Anderson \& Prior 1992, Edgerton et al. 1994, 1995,

\footnotetext{
•Corresponding author. E-mail: leigh.owens@jcu.edu.au
}

Owens \& McElnea 2000), bacteria (Ketterer et al. 1992, Owens et al. 1992, Eaves \& Ketterer 1994, Webster 1995) and ectoparasites (Herbert 1987, 1988) have been reported in Australia, and the presence of Cherax bacilliform virus (Groff et al. 1993) and rickettsiae (Jimenez \& Romero 1997) also been reported outside Australia.

During the summer of 1990, heavy losses were reported from growout ponds of commercially farmed redclaw in Australia. Initially, 3 to 4 deaths were seen each day, but after the transfer of redclaw to fresh ponds, mortalities reached up to $300 \mathrm{~d}^{-1}$ over 3 to $4 \mathrm{~d}$. By the end of the growing period, mortalities totaled 24000 (Ketterer et al. 1992). Histological examinations found a rickettsia-like bacteria and ectoparasites, Lagenophrys sp., associated with the infected crayfish. Similarly, Edgerton et al. (1995) found the presence of 2 species of rickettsiae, 1 in the cytoplasm of hepatopancreatic cells (Edgerton \& Prior 1999) and 1 in the connective tissues throughout moribund crayfish. Rickettsial disease has recently been identified in Ecuador 
with mortalities up to $80 \%$ in several farms (Jimenez \& Romero 1997). The bacteria exhibited morphology and characteristics similar to those reported by Edgerton et al. (1995).

Rickettsiae are Gram-negative, obligate parasitic bacteria that multiply only within the host cells (Weiss \& Moulder 1984). They are well known amongst terrestrial species with insects and arachnids serving as secondary hosts or vectors (Larrson 1982). However, in recent years, rickettsiae have been reported as the aetiological agent of diseases in a number of aquatic organisms including teleosts (Fryer \& Lannan 1994) and molluscs (Le Gall et al. 1991). These bacteria may also be the aetiological agent of disease in redclaw and have the potential to devastate the redclaw industry worldwide.

To date, no studies have been conducted beyond microscopic observations to determine the nature of the disease. Accordingly, this study was designed to investigate the pathogenicity of the bacteria, the possible modes of transmission, and the taxonomic placement relative to other species of rickettsia and closely related bacteria

\section{MATERIALS AND METHODS}

Rickettsial isolate. Rickettsiae used in the study were obtained from an infected farm in far northern Queensland which exhibited daily mortalities of redclaw. The isolate of rickettsia from Cherax quadricarinatus, named TO-98, was purified according to the procedures adopted by Le Gall \& Mialhe (1992) with slight modification. In brief, hepatopancreata, eyestalks, gills and connective tissues were dissected and homogenised in physiological saline $(0.9 \%)$ and Tween-80 (0.1\%) (PST). The homogenate was sieved through a nylon cloth to remove larger cellular material and washed twice by centrifugation $(3500 \times g$, $30 \mathrm{~min}$ at $6^{\circ} \mathrm{C}$ ). The supernatant was discarded and the pellet resuspended in PST. Several differential centrifugations using discontinuous sucrose gradients (15 and $50 \%$ ) were performed to concentrate the bacteria. Purification was achieved with an isopycnic centrifugation on a Urografin TM (Scherring) discontinuous density gradient (14 to 21 to $28 \%$ ) (V/V). The interfaces at 14 to $21 \%$ and 21 to $28 \%$ were collected, diluted in TN buffer $(20 \mathrm{mM}$ Tris- $\mathrm{HCl}, 400 \mathrm{mM} \mathrm{NaCl}$ at $\mathrm{pH} 7.5)$, pelleted and resuspended in TN buffer. The purified bacteria were plated onto nutrient agar and identified by Gram stain under light microscopy. Any growth on the nutrient agar was considered due to contaminating heterotrophic bacteria, and the relevant isolate was discarded. Contaminants were removed by filtration through 1.2 and $0.45 \mu \mathrm{m}$ filter.
Cell culture. Propagation of rickettsia from Cherax quadricarinatus was attempted in fathead minnow $P i-$ mephales promelas (FHM), bluegill Lepomis macrochirus fry (BF-2) and Spodoptera moth (Sf-9) cell lines. Cells were cultured in $25 \mathrm{~cm}^{2}$ plastic culture flasks (Corning Glass Works, New York) containing Dulbecco's modified medium (DMEM) supplemented with $5 \%$ foetal bovine serum (FBS) for the first two, while the latter was propagated in insect medium TC-100 supplemented with $10 \% \mathrm{FBS}$. Cells were incubated at $28^{\circ} \mathrm{C}$, and media was changed when the monolayers were confluent. Cells were inoculated with rickettsia directly after their passage.

Inoculation of hens' eggs. Purified rickettsia $\left(100 \mathrm{l}^{-1}\right)$ suspended in TN buffer were inoculated into the yolk sac of specific pathogen-free (for rickettsia), embryonated hens' eggs at $6 \mathrm{~d}$ of age. The eggs were incubated at 28,32 and $36^{\circ} \mathrm{C}$, and harvested after $11 \mathrm{~d}$ post-inoculation. Harvested material was examined by Gram stain

DNA extraction. Infected redclaw were collected from a farm in far northern Queensland and rickettsial isolates were purified as described above. DNA from purified rickettsia was extracted by $100 \mu \mathrm{g} \mathrm{ml} \mathrm{m}^{-1}$ Proteinase $\mathrm{K} / 1 \%$ sodium dodecyl sulfate (SDS) digestion followed by 2 phenol-chloroform and 1 chloroformisoamyl alcohol extraction. After an absolute-ethanol precipitation, the purified DNA was washed with $70 \%$ ethanol and resuspended in $50 \mu \mathrm{l}$ TE buffer.

Amplification of rRNA genes. The reaction mixes for PCR contained: $5 \mu$ l of $10 \times$ PCR buffer, $5 \mu l$ dNTPs ( $2 \mathrm{mM}$ ), 100 pmol of each of the 2 primers, 0.1 unit of Taq polymerase $10 \mu \mathrm{MgCl}_{2}$, and sterile double distilled water to $50 \mu \mathrm{l}$. Light mineral oil was overlaid onto each reaction mix. The primers (5' to $3^{\prime}$ orientation) were forward 63for 16SrRNA CAG GCC TAA CAC ATG CAA CTC, and reverse 1387rev 16srRNA GGG CGG WGT GTA CAA GGC, where $\mathrm{W}=\mathrm{A}$ or $\mathrm{T}$. (See 'Acknowledgements' for primer source.) The thermal program comprised 30 cycles of denaturation at $94^{\circ} \mathrm{C}$ for $3 \mathrm{~min}, 95^{\circ} \mathrm{C}$ for $1 \mathrm{~min}$, hybridization at $55^{\circ} \mathrm{C}$ for 1 min and extension at $72^{\circ} \mathrm{C}$ for $90 \mathrm{~s}$. The products were kept at $4^{\circ} \mathrm{C}$ at the completion of the cycles. Products were run on $1.0 \%$ agarose gel made in TAE buffer (0.04 M Tris-acetate, $0.001 \mathrm{M}$ EDTA) and contained $0.0005 \%$ ethidium bromide. The gel was run at $80 \mathrm{~V}$ for $60 \mathrm{~min}$. The DNA was extracted and purified from the agarose gel using QIAquick Gel Extraction Kit (QIAGEN, Germany) according to the manufacturer's instructions.

Purified PCR product was sequenced with dRhodamine Terminator Cycle Sequencing Ready Reaction mix (ABI Prism, PE Applied Biosystems). In addition to the 2 primers above, the following rickettsial primers (5' to $3^{\prime}$ orientation) PC* (CTA CGG GAG GCA GCA 
GTG GG), PC (CTA CGG GAG GCA GTG GG), and PF' (CAT GGC TGT CGT CAG CTC GT) were included to bridge the sequence. (See 'Acknowledgements' for primer source.) The thermal cycling program consisted of $96^{\circ} \mathrm{C}$ for $30 \mathrm{~s}, 50^{\circ} \mathrm{C}$ for $15 \mathrm{~s}$ and $60^{\circ} \mathrm{C}$ for 4 min repeated for 25 cycles.

DNA analysis. A consensus sequence was developed by aligning a minimum of 4 replicates and a maximum of 7 overlapping frames using the program Sequencher. The sequence was then aligned with 18 published sequences of Rickettsiales and closely related bacteria using the multiple aligning software, Clustal $X$. Once the sequences were aligned, the corrected level of nucleotide divergence of the sequences was calculated using the program PAUP.

Experimental infections. The infectivity trial was conducted in twelve $170 \mathrm{l}$ aquaria containing 5 juvenile redclaw weighing between 10 and $15 \mathrm{~g}$ in each tank. Purified TO-98 was centrifuged at $6000 \times g$ for 10 min at $6^{\circ} \mathrm{C}$ and resuspended in DMEM. A total of $100 \mathrm{ml}$ of inoculum was injected into each experimental crayfish in the first abdominal segment. The placebo control was injected with $100 \mu \mathrm{l}$ of DMEM. Experimentally infected and uninfected control crayfish were maintained separately under similar feeding and water quality conditions. All treatments were in duplicate. All surviving crayfish at the end of the $28 \mathrm{~d}$ pathogenicity trial were examined for the presence of rickettsia.

Redclaw heavily infected with rickettsia were macerated and fed to experimental crayfish, which were starved for $24 \mathrm{~h}$ prior to feeding. Uneaten flesh was removed $2 \mathrm{~h}$ later to avoid water contamination. Purified rickettsia were placed directly into the tank in order to determine the possibility of direct transmission.

Statistical analysis. Testing for significant differences in survival was by a 1-way analysis of variance (ANOVA) and significant variation between the treatment means was by using Tukey HSD analysis within the SPSS statistical package.

\section{RESULTS}

\section{Growth of the rickettsia in embryonated hens' eggs}

The yolk sac membranes of embryonated hens' eggs inoculated at Day 6 were harvested at Day 11. The eggs were successful for the cultivation of rickettsia at $36^{\circ} \mathrm{C}$, but the embryo failed to grow at 28 and $32^{\circ} \mathrm{C}$ and no rickettsia were recovered (Table 1).
Table 1. Results of inoculation of rickettsiae into embryonic hens' eggs under a number of conditions

\begin{tabular}{|lccc|}
\hline $\begin{array}{l}\text { Temperature } \\
\left({ }^{\circ} \mathrm{C}\right)\end{array}$ & $\begin{array}{r}\text { Number of } \\
\text { eggs tested }\end{array}$ & $\begin{array}{c}\text { Presence } \\
\text { of rickettsia }\end{array}$ & $\begin{array}{c}\% \text { of } \\
\text { infection }\end{array}$ \\
\hline 28 & 6 & No & 0 \\
32 & 9 & No & 0 \\
36 & 12 & Yes & 75 \\
\hline
\end{tabular}

\section{Cell culture}

The current rickettsia of Cherax quadricarinatus failed to grow in any of the 3 cell lines, despite an additional re-inoculation with the specific rickettsial isolate (TO-98).

\section{Experimental infections}

Rickettsial infections were established in all crayfish injected with TO-98. Grossly, the infected crayfish looked normal but were extremely lethargic shortly before death. Upon death, the crayfish became reddened and putrefied with the eyes of highly infected crayfish totally necrotised and the hepatopancreas liquefied. Mortalities were first detected $2 \mathrm{~d}$ postinfection in the waterborne treatment (Fig. 1), but no rickettsia were recovered. The inoculated treatment held at $28^{\circ} \mathrm{C}$ had significantly higher mortalities with $70 \%$ mortalities between 2 and $12 \mathrm{~d}$ post-injection, and total mortality by $20 \mathrm{~d}$ post-injection. Gram stains of impression smears of the eyestalk revealed masses of Gram-negative bacteria resembling those of rickettsiae. These bacteria failed to grow on nutrient agar.

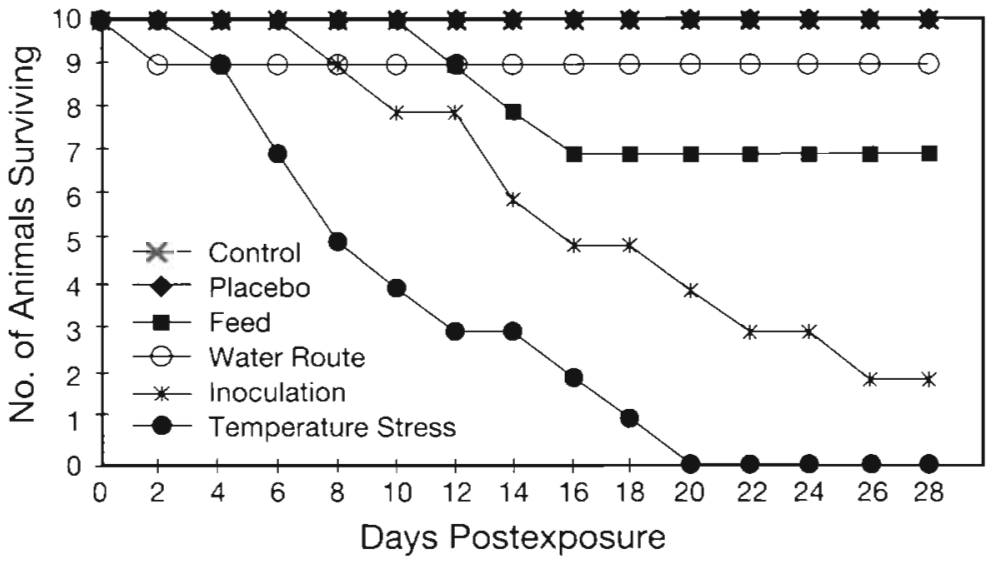

Fig. 1. Cherax quadricarinatus. Survival of redclaw over a $28 \mathrm{~d}$ pathogenicity trial with rickettsial isolate TO-98 administered by inoculation $\left(24^{\circ} \mathrm{C}\right)$, bath, a feeding route, and inoculation without and with a $28^{\circ} \mathrm{C}$ temperature stress 
The inoculated crayfish held at ambient temperatures showed trends similar to those held at the higher temperature and with mortalities at $8 \mathrm{~d}$ post-injection. Gradual mortalities were reported throughout the trial period and at the termination of the experiment, survival was $20 \%$. In contrast, feed transmission treatments had a total of $70 \%$ survival by Day 28 , with mortalities occurring between Days 10 and 16. No crayfish from the control and placebo treatments died during the experimental period.

One-way ANOVA found significant difference $(F=$ $37.3 \mathrm{df}=5,11, \mathrm{p}<0.01)$ between the treatments. Tukey's HSD revealed a significant difference $(p<0.05)$ between both experimentally injected groups and the placebo, control, feed infected and waterborne treatment groups (Table 2). However, no significant difference was found between the rickettsial-inoculated-groups held at ambient and at raised water temperatures.

\section{Re-isolation of rickettsia}

Rickettsia were re-isolated and purified from all experimentally infected crayfish groups (Table 3). If the isolates contained small, Gram-negative rods with no growth on nutrient agar, it was presumed that they were rickettsia and that Koch's postulates had been confirmed. In contrast, no rickettsia were present in the placebo and control treatments. Despite the fact that no rickettsia were isolated in the moribund crayfish from the water transmission treatment, low numbers of rickettsia were recovered from $40 \%$ of the crayfish in this treatment. Similarly, the oral-infected treatment had a high infection rate at $50 \%$.
Table 3. Recovery rate of rickettsia from experimental Cherax quadricarinatus

\begin{tabular}{|lccr|}
\hline Treatment & $\begin{array}{c}\text { No. of } \\
\text { samples } \\
\text { tested }\end{array}$ & $\begin{array}{c}\text { No. positive } \\
\text { for } \\
\text { rickettsia }\end{array}$ & $\begin{array}{c}\% \\
\text { positive }\end{array}$ \\
\hline Control & 10 & 0 & 0 \\
Placebo & 10 & 0 & 0 \\
Waterborne & 10 & 4 & 40 \\
Oral route & 10 & 5 & 50 \\
Inoculation & 10 & 10 & 100 \\
Inoculation + & 10 & 10 & 100 \\
temperature stress & & & \\
\hline
\end{tabular}

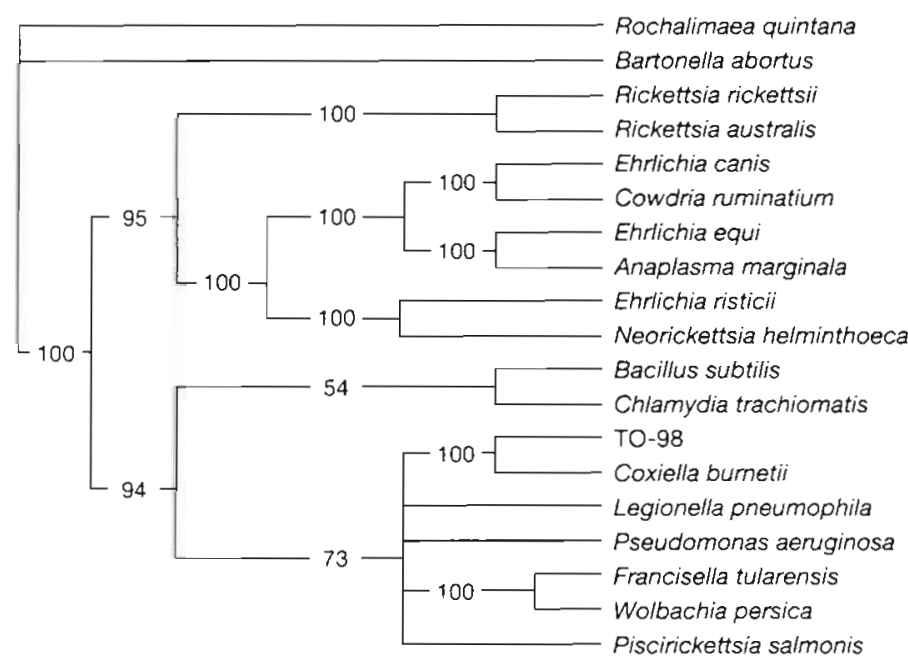

Fig. 2. Phylogenetic tree showing relationships amongst the rickettsiae in this study representing members of the $\alpha$ - and $\gamma$-subgroups of Proteobacteria. The bootstrap distances were calculated by the program PAUP
Table 2. Tukey HSDs showing the mean differences in percentage survival (top value) and $p$-value (bottom value)

\begin{tabular}{|c|c|c|c|c|c|c|}
\hline Treatment & Control & Placebo & $\begin{array}{l}\text { Oral } \\
\text { route }\end{array}$ & $\begin{array}{l}\text { Water- } \\
\text { borne }\end{array}$ & $\begin{array}{l}\text { Inocu- } \\
\text { lation }\end{array}$ & $\begin{array}{c}\text { Inoculation }+ \\
\text { temperature } \\
\text { stress }\end{array}$ \\
\hline Control & - & & & & & \\
\hline Placebo & $\begin{array}{c}0 \\
1.0\end{array}$ & - & & & & \\
\hline Oral route & $\begin{array}{l}10 \\
0.9\end{array}$ & $\begin{array}{l}10 \\
0.9\end{array}$ & - & & & \\
\hline Waterborne & $\begin{array}{c}30 \\
0.15\end{array}$ & $\begin{array}{c}30 \\
0.15\end{array}$ & $\begin{array}{l}20 \\
0.4\end{array}$ & - & & \\
\hline Inoculation & $\begin{array}{c}80 \\
0.002\end{array}$ & $\begin{array}{c}80 \\
0.002\end{array}$ & $\begin{array}{c}70 \\
0.003\end{array}$ & $\begin{array}{c}50 \\
0.02\end{array}$ & - & \\
\hline $\begin{array}{l}\text { Inoculation }+ \\
\text { temperature } \\
\text { stress }\end{array}$ & $\begin{array}{l}100 \\
0.0\end{array}$ & $\begin{array}{l}100 \\
0.0\end{array}$ & $\begin{array}{c}90 \\
0.001\end{array}$ & $\begin{array}{c}70 \\
0.003\end{array}$ & $\begin{array}{l}20 \\
0.4\end{array}$ & - \\
\hline
\end{tabular}

\section{$16 S$ rRNA sequencing}

Phylogenetic tree

The partial 16S rRNA sequence characterised 1325 nucleotides of the rickettsia from Cherax quadricarinatus. When the sequence was aligned with other rickettsial and closely related bacterial $16 \mathrm{~S}$ rRNA sequences obtained from Genbank, TO-98 appeared to be a member of the $\gamma$-subgroup of the Proteobacteria, with Coxiella burnetii its nearest neighbour (Fig. 2). The tree branched with C. burnetii at approximately the same point as with Wolbachia persica with Francisella tularensis, after the splitting off of Piscirickettsia salmo- 
nis, Legionella pneumophila, and Pseudomonas aeruginosa. Other genera, Rickettsia and Ehrlichia, which belong to the $\alpha$-subgroup, diverged very early from the $\gamma$-subgroup. The bootstrap values for the most parsimonious tree were relatively high between 94 and 100\% for all nodes except the node connecting Bacillus subtilis and Chlamydia trachiomatis, and that connection to the $\gamma$-subgroup, where the bootstrap values were 54 and $73 \%$ respectively.

\section{Evolutionary distances}

Pair-wise comparison of TO-98 with other members of Rickettsiaceae and closely related bacteria are summarised in Table 4. TO-98's nearest neighbour, Coxiella burnetii, had 55 nucleotides substitutions within the partial sequence of 1325 base pairs or equivalent to $95.6 \%$ similarities (Table 4). Of 18 species compared to this rickettsia, the next most closely related bacterium was Legionella pneumophila at $86.7 \%$. This rickettsia is not closely related to species of Ehrlichia, Rickettsia and Neorickettsia with similarities between 78.4 and $82.3 \%$, while rickettsial members of the $\gamma$-subgroup were approximately $84 \%$.

\section{Primary structure}

The aligned primary sequences revealed a number of differences between the $\alpha$ - and $\gamma$-subgroups (Fig. 3). The most drastic differences occurred at positions 141 to 157,347 to 374 , and 899 to 915 . Despite having 55 nucleotide substitutions between TO-98 and Coxiella burnetii, the most significant stretch occurred at position 368 to 379 (Fig. 3). The remaining changes were subtle with only 1 or 2 continuous base pair substitutions along the sequence.

\section{DISCUSSION}

The organism isolated from infected farmed redclaw was confirmed by Koch's postulates as the aetiological agent of the disease. Previous publications (Ketterer et al. 1992, Owens et al. 1992) and our findings suggested that the organism is an obligate intracellular pathogen that depends on living host cells for survival, which is very characteristic of the Order Rickettsiale. Owens et al. (1992) suggested that the

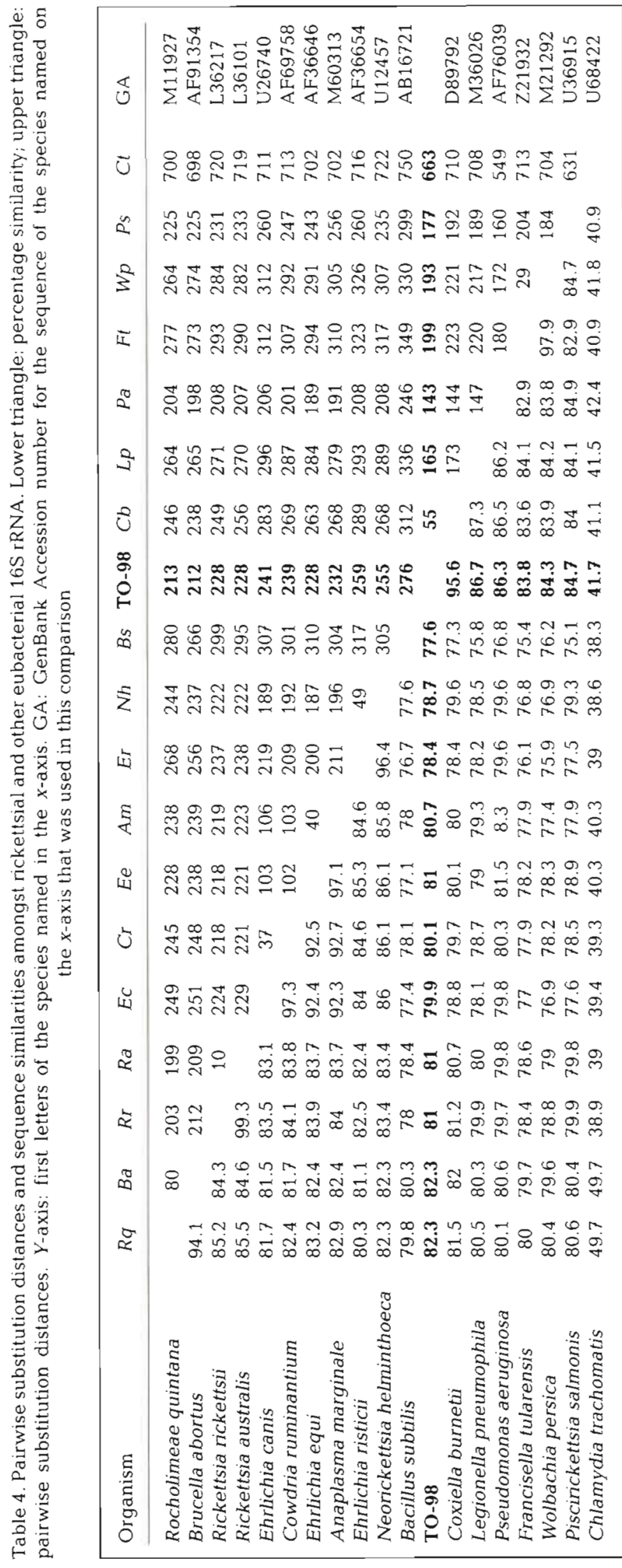




F. tularensis
W. persica
R. quintana
B. abortus
R. rickettsii
R. australis
E. canis
C. ruminatum
E. equi
A. marginalla
E. nisticii
N. helminthoeca
B. subtilis
TO-98
C. burnetii
L. pneumorphila
P. aeruginosa
P. salmonis
C. trachiomatis

F. tularensis

W. persica

R. quintana

B. abortus

R. rickettsii

R. australisT

E. canis

C. ruminatuim

E. equi

A. marginalla

E. risticii

N. helminthoeca

$B$. subtilis

TO-98

C. burnetii

L. pneumorphila

$P$. aeruginosa

$P$. salmonis

C. trachiomatis

\begin{tabular}{|c|c|c|c|}
\hline & $\mathrm{CT}_{-}$ & & \\
\hline$G T$ & $\mathrm{G}-\ldots-\mathrm{CT}-$ & TTCGAGCTGT & $G$ \\
\hline $\mathrm{AT}$ & $\ldots-\ldots-\ldots$ & $\ldots \ldots-\mathrm{TAT}_{\mathrm{T}}$ & 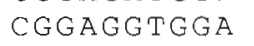 \\
\hline$A T$ & -------- & $-----\mathrm{TAT}$ & CAAATGA \\
\hline$A T$ & $----\ldots---$ & $-\cdots-\cdots \mathrm{TAT}$ & $\mathrm{G} z$ \\
\hline $\mathrm{AT}$ & $-\ldots \ldots \ldots$ & $\ldots-\ldots-\mathrm{TAT}$ & $\mathrm{CG}$ \\
\hline & $\mathrm{T} \cdots \cdots \cdots$ & $\ldots \ldots-\mathrm{TAT}$ & $\mathrm{CG}$ \\
\hline $\mathrm{AT}$ & $\mathrm{T}-\cdots-\cdots$ & $\ldots-\cdots$ TAT & $\mathrm{CGCT} 2$ \\
\hline & $\mathrm{T}-\cdots-\cdots$ & $------\mathrm{TAT}$ & - \\
\hline & $\mathrm{T} \cdots \cdots \cdots$ & $----\cdots$ & $\mathrm{C}$ \\
\hline $\mathrm{T}$ & $\mathrm{T}-\cdots-\cdots$ & $-\cdots---\mathrm{TAT}$ & $\mathrm{TC}$ \\
\hline $\mathrm{AT}$ & $\mathrm{T}--------$ & $\ldots-\ldots-T_{A}$ & $\mathrm{TAT}$ \\
\hline A T & AAAAGGTGG- & CTT & $\mathrm{CZ}$ \\
\hline$C G$ & $\mathrm{GGG}-\mathrm{GATCT}-$ & $\mathrm{TCGGACCTCG}$ & $\mathrm{CG}$ \\
\hline & NGG-GATCT - & $\mathrm{TCGGACCTCG}$ & TGCTAT \\
\hline & $\mathrm{GGG}-\mathrm{GACCT}-$ & $\mathrm{TCGGGCCT}$ & CGCTTT \\
\hline & $\mathrm{GGG}-\mathrm{GATCT}-$ & $\mathrm{TCGGACC}$ & CGCTAT \\
\hline & GGCCTCTATA & TATAAGCTCT & TGCTAG \\
\hline $\mathrm{ACCT} T$ & $\mathrm{AAG}--\mathrm{TCG}$ & TGACTCAACC & CGCAAGGGAG \\
\hline & 141 & 151 & 161 \\
\hline
\end{tabular}

\begin{tabular}{|c|c|c|c|}
\hline $\mathrm{CT}$ & CAAGGTTAAT & TTGGGG & 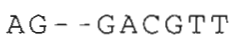 \\
\hline $\mathrm{CT}$ & TGAGGTTAAT & NGCCTTTAGG & $\mathrm{AAT}-\mathrm{G}$ \\
\hline & ---- & $\ldots \ldots \ldots$ & $---\mathrm{TG}$ \\
\hline & ----- & $\ldots \ldots \ldots-\ldots$ & $\ldots$ TGACGGT \\
\hline & ------ & --------- & $\operatorname{CGTT}$ \\
\hline & ---- & ----- & -- \\
\hline & ----- & $-\cdots-\cdots---$ & $\rightarrow-$ \\
\hline-- & $-\ldots$ & ---------- & --- \\
\hline & & ------ & -- \\
\hline & & & $\ldots$ \\
\hline & ---- & & -- \\
\hline-- & $-----\cdots--$ & --------- & --- \\
\hline$G T$ & GCCGTTCAAA & $T A G$ & $\mathrm{CCT}$ \\
\hline $\mathrm{T}$ & $T$ & -- & \\
\hline $\operatorname{TCT}$ & GGTAAT & $\mathrm{ATC}$ & $G-T T$ \\
\hline TTG & ATAGGTTAAG & $A G O$ & $\mathrm{C}-\mathrm{T}$ \\
\hline $\mathrm{GCA}$ & GTAAGTTAAT & $\mathrm{ACC}$ & $T-T$ \\
\hline GTA & AGCTAATTAA & T TG & AAT \\
\hline & $A$ & $\mathrm{GA}$ & $---\mathrm{T}$ \\
\hline & 351 & & 371 \\
\hline
\end{tabular}

Fig. 3. Regions along the aligned 16S IRNA sequences of $\alpha$-and $\gamma$-subgroups of Proteobacteria displaying the variations in nucleotides at the 2 most disparate points. -: a gap or missing nucleotide; N: not known. For full generic names, see Table 4

rickettsia of Cherax quadricarinatus might be a member of the genus Rickettsiella, based on morphological and pathological evidence. However, the present findings demonstrated that the rickettsia of $C$. quadricarinatus is more closely related to Coxiella burnetii in the $\gamma$-subgroup of the phylum Proteobacteria. Although this rickettsia may bear some phenotypic resemblance to members of the $\alpha$-subgroup, genotypic relationships are quite distinct (Weiss \& Moulder 1984). Therefore, the common parasitic existence of the rickettsiae must either be very ancient in origin or have undergone convergence evolution, arising independently from 2 lineages (Weisburg et al. 1989).
Coxiella (Philip 1943) Philip 1948 (Skerman et al. 1980 ) is a monospecific genus with a wide geographical distribution and diverse pathogenic characteristics. Beside the close similarities with the rickettsia of Cherax quadricarinatus, both of these bacteria also share a common geographical range in Australia. To date, rickettsial disease has not been detected from any other freshwater crayfish in Australia or worldwide, despite the diverse crayfish fauna (Rouse 1995). The host and specific nature of this rickettsia and its distribution suggests that the divergence from Coxiella burnetii could be a recent event. An approximation on the time of divergence may be obtained by applying the molecular clock calibrations proposed for prokary- 
otic 16S rRNA genes (Ochman \& Wilson 1987). It suggests the divergence of $16 \mathrm{~S}$ rRNA nucleotide sequence between 2 bacterial taxa occurs at a rate of approximately $1 \%$ per 50 million yr (Weisburg et al. 1989). Based on this approximation, the divergence of the rickettsia of $C$. quadricarinatus and $C$. burnetii occurred 200 million yr ago, during which time arthropods were very abundant (Hickman \& Roberts 1994). We suggest there is enough evidence of divergence and distinctness to submit that this rickettsia from Cherax quadricarinatus is a new species most closely related to Coxiella burnetii and that it should be named Coxiella cheraxisp. nov.

The ability of the rickettsiae to grow in yolk sacs of embryonic chicken eggs at $36^{\circ} \mathrm{C}$ further supports that this rickettsial organism is a member of the genus Coxiella in the tribe Rickettsieae of the family Rickettsiaceae. $C$. burnetii is readily cultivated in the yolk sacs of developing chicken embryos, and is highly resistant to adverse physical and chemical agents (Woldehiwet \& Aitken 1993). At present, only 2 other published studies, by Harshbarger et al. (1977) and Buchanan (1978), have successfully propagated a rickettsia of aquatic origin in yolk sac embryos of developing chicken eggs. Further work is needed on the culture of this organism in embryonated eggs.

Evidence of the gills providing an effective and fast infection route have been demonstrated for a number of bacteria including Piscirickettsia salmonis (Branson \& Nieto Diaz Munoz 1991, Almendras et al. 1997), rickettsia-like organisms of Placopecten magellanicus (Gulka \& Chang 1984), and Aeromonas salmonicida (Effendi \& Austin 1995). The gills may provide an important site of transmission during the natural infection of rickettsial disease (Gulka \& Chang 1984). As the waterborne route seemed to infect crayfish in the present study, the gills are a possible site of infection.

The ability of the rickettsia of Cherax quadricarinatus to survive extracellularly (i.e. in the water) for an extended period has also been observed with Coxiella burnetii (Weiss \& Moulder 1984) and Piscirickettsia salmonis (Fryer \& Lannan 1994). The time over which C. burnetii and this current rickettsia remain infective is uncertain, but Fryer \& Lannan (1994) demonstrated that $P$. salmonis could survive and remain infective for up to $15 \mathrm{~d}$. The presence of a vector in most mammalian cases of rickettsial disease suggests that a secondary arthropod host may be involved (Almedras et al. 1997). Perhaps, C. quadricarinatus is acting as an alternative arthropod host to some vertebrate.

Acknowledgements. Drs Catriona McElnea and Jane Oakey gave advice for the PCR and sequencing. Dr Dave Miller and Lyn Hughes supplied the rickettsial primers and advice on their use.

\section{LITERATURE CITED}

Almendras FE, Fuentealba IC, Jones SRM, Markham F, Spangler E (1997) Experimental infection and horizontal transmission of Piscirickettsia salmonis in freshwater-raised Atlantic salmon, Salmo salar L. J Fish Dis 20:409-418

Anderson IA, Prior HC (1992) Baculovirus infections in the mud crab. Scylla serrata and a freshwater crayfish, Cherax quadricarinatus from Australia. J Invertebr Pathol 60: 265-273

Branson EJ, Nieto Diaz-Munoz D (1991) Description of a new disease condition occurring in farmed coho salmon, Oncorhynchus kisutch (Walbaum), in South America. J Fish Dis 14:149-156

Buchanan JS (1978) Cytological studies on a new species of rickettsia found in association with a phage in the digestive gland of the marine bivalve mollusc, Tellina tenius (da Costa). J Fish Dis 1:27-43

Eaves LE, Ketterer PJ (1994) Moralities in red claw crayfish Cherax quadricarinatus associated with systematic Vibrio mimicus infection. Dis Aquat Org 19:233-237

Edgerton B (1996) Viruses of freshwater crayfish. PhD thesis, James Cook University, Townsville

Edgerton BF, Prior HC (1999) Description of a hepatopancreatic rickettsia-like organism in the redclaw crayfish Cherax quadricarinatus. Dis Aquat Org 36:77-80

Edgerton B, Owens L, Glasson B, De Beer S (1994) Description of a small dsRNA virus from freshwater crayfish Cherax quadricarinatus. Dis Aquat Org 18:63-69

Edgerton B, Owens L, Harris L, Thomas A, Wingfield M (1995) A health survey of farmed redclaw crayfish, Cherax quadricarinatus (von Martens), in tropical Australia. Freshw Crayfish 10:322-338

Effendi I, Austin B (1995) Dormant/unculturable cells of the fish pathogen Aeromonas salmonicida. Microb Ecol 30: $183-192$

Fryer JL, Lannan CN (1994) Rickettsial infection of fish. Annu Rev Fish Dis 6:3-13

Groff JM, McDowell T, Friedman CS, Hedrick RP (1993) Detection of a nonoccluded baculovirus in the freshwater crayfish Cherax quadricarinatus in North America. J Aquat Anim Health 5:275-279

Gulka G, Chang PW (1984) Pathogenicity and infectivity of a rickettsia-like organism in the sea scallop, Placopecten magellanicus. J Fish Dis 8:309-318

Harshbarger JC, Chang SC (1977) Chlamydiae (with phages), Mycoplasma, and Rickettsiae in Chesapeake Bay bivalves. Science 196:666-668

Herbert B (1987) Notes on diseases and epibionts of Cherax quadricarinatus and C. tenuimanus (Decapoda: Parastacidae). Aquaculture 64:165-173

Herbert JW (1988) Infection of Cherax quadricarinatus (Decapoda: Parastacidae) by the microsporidium Thelohania $\mathrm{sp.}$ (Microsporida: Nosematidae). J Fish Dis 11:301-308

Hickman CP, Roberts LS (1994) Biology of animals. Wm. C. Brown Publishers, Dubuque

Jimenez R, Romero X (1997) Infection by intracellular bacterium in red claw crayfish, Cherax quadricarinatus (von Martens) in Ecuador. Aquacult Res 28:923-929

Jones CM (1990) The biology and aquaculture potential of the tropical freshwater crayfish Cherax quadricarinatus. Queensland Department of Primary Industries, Information Series Q 190028, Brisbane

Ketterer PJ, Taylor DJ, Prior HC (1992) Systematic rickettsialike infection in farmed freshwater crayfish, Cherax quadricarinatus. In: Shariff $M$, Subasinghe RP, Arthur JR (eds) Diseases in Asian aquaculture 1. Fish Health Section, 
Asian Fisheries Society, Manila, Philippines, p 173-179

Larrson R (1982) A rickettsial pathogen of the amphipod Rivulogammarus pulex. J Invertebr Pathol 40:28-35

Le Gall G, Mialhe E (1992) Purification of Rickettsiales-like organisms associated with Pecten maximus (Mollusca: Bivalvia): serological and biochemical characterization. Dis Aquat Org 12:215-220

Le Gall G, Miahle E, Chagot D, Grizel H (1991) Epizootiological study of rickettsiosis of the Saint-Jacques scallop Pecten maximus. Dis Aquat Org 10:139-145

Medley PB, Jones CM, Avault JW (1994) A global prospective of the culture of Australian redclaw crayfish, Cherax quadricarinatus: production, economics and marketing. World Aquacult 25(4):6-13

Ochman H, Wilson AC (1987) Evolution in bacteria: evidence of a universal substitution rate in cellular genomes. $\mathrm{J}$ Mol Evol 26:74-86

Owens L, McElnea C (2000) Natural infection of the redclaw crayfish Cherax quadricarinatus with presumptive spawner-isolated mortality virus. Dis Aquat Org 40:219-223

Owens L, Muir P, Sutton D. Wingfield M (1992) The pathology of microbial diseases in tropical Australian Crustacea. In: Shariff M, Subasinghe RP, Arthur JR (eds) Diseases in

Editorial responsibility: Timothy Flegel,

Bangkok, Thailand
Asian aquaculture 1. Fish Health Section, Asian Fisheries Society, Manila, Philippines, p 165-172

Rouse DB (1995) Australian crayfish culture in the Americas. J Shellfish Res 14:569-572

Skerman VBD, McGowan V. Sneath PHA (eds) (1980) Approved lists of bacterial names. Int $\mathrm{J}$ Syst Bacteriol 30: $225-420$

Webster NS (1995) The isolation and identification of bacterial flora from the redclaw crayfish, Cherax quadricarinatus. Honours thesis, James Cook University, Townsville, Australia

Weisburg WG, Dobson ME, Samuel JE, Dasch GA, Mallavia LP, Baca O, Mandelco L, Sechrest JE, Weiss E, Woese CR (1989) Phylogenetic diversity of the Rickettsiae. J Bacteriol 171:4202-4206

Weiss E, Moulder JW (1984) Order I. Rickettsiales Gieszczkiewicz 1939, 25AL. In: Krieg NR (ed) Bergey's manual of systematic bacteriology, Vol 1 Williams and Wilkins, Baltimore, MD, p 687-729

Woldehiwet Z, Aitken ID (1993) Coxiellosis (Q Fever), In: Woldehiwet Z, Ristkic M (eds) Rickettsial and chlamydial diseases of domestic animals. Pergamon Press, Oxford, p $1-26$

Submitted: December 20, 1999; Accepted: February 23, 2000 Proofs received from author(s): May 29, 2000 